\title{
INSTRUMEN EKONOMI ATAU PRIVATISASI PENGELOLAAN LINGKUNGAN? KOMENTAR ATAS RUU JASA LINGKUNGAN'
}

\author{
Andri G. Wibisana ${ }^{2}$
}

Indonesia's Regional Representatives Board is planning to submit a Bill on environmental services. The Bill proposes the establishment of a new institution in managing environmental service fund, which is collected through a user-charge system. This new institution is expected to be an independent Commission of Environmental Funds Management, of which commissioners are responsible only to the President. The author finds that the spirit of the Bill has nothing to do with the needs to implement economic instruments in terms of user charge. Instead, the Bill stems from the needs to privatize public goods such as environmental services. The spirit can be seen in the forms of reference to Hardin's "the Tragedy of the Commons", in which public goods are considered a form of inefficiency in the allocation of resources that will eventually lead to the overexploitation of the goods. In addition, the spirit of privatization can also be seen in the Bill's proposal to hand over the tasks of the Commission, which include planning, execution, and monitoring, to private entities. The author argues that, with such spirit of privatization in the management of natural resources, the Bill is actually inconstitutional, and hence, should be rejected.

Kata kunci: hukum lingkungan, privatisasi, ruu jasa lingkungan

\section{Pendahuluan}

Kebijakan pengelolaan lingkungan sampai saat ini lebih banyak bertumpu pada pendekatan Command and Control (CAC), atur dan awasi, yang efektifitasnya akan sangat tergantung pada regulasi (dalam bentuk standar dan perizinan), kemampuan aparat untuk mengontrol tingkah laku masyarakat (agar sesuai dengan standar dan syarat-syarat yang tercantum di

1 Tulisan ini merupakan penyempurnaan atas makalah penulis yang disampaikan pada Seminar RUU tentang Jasa Lingkungan, Bandung, 1 Desember 2008.

${ }^{2}$ Sarjana Hukum (1998) dari Fakultas Hukum Universitas Indonesia; LLM (2002) dari Master Program on Law and Economics, Utrecht University; Ph.D. (2008) dari Maastricht University. Saat ini bekerja sebagai Pengajar Hukum Lingkungan pada Fakultas Hukum UI. 
dalam izin yang telah diberikan), dan kemampuan Pemerintah untuk tidak hanya mendeteksi pelanggaran hukum, tetapi juga memberikan sanksi yang memadai (dalam arti mampu memberikan efek jera) pada setiap pelanggaran yang terjadi. Tentu saja tidak ada yang salah dari pendekatan CAC tersebut di atas. Persoalannya, penegakan hukum di Indonesia sudah sering dikeluhkan sangat tidak efektif dan efisien.

Alih-alih mencoba memperbaiki system politik, hukum, dan birokrasi yang rusak tersebut serta melihat bahwa pencemaran dan kerusakan lingkungan muncul dari kegagalan pasar, beberapa kalangan justru melihat persoalan lemahnya penegakan hukum dari sisi yang lebih ideologis: Terlalu bannyak campur tangan pemerintah pada dunia usaha, yang pada akhirnya justru menjadi sumber dari korupsi dan kolusi. Pencemaran dan kerusakan lingkungan terjadi karena kegagalan pemerintah.

Alhasil, instrumen ekonomi (economic instruments atau market-based approach) dan pendekatan sukarela (voluntary approach atau moral suasion) dimunculkan sebagai lawan dari CAC, karena pendekatan-pendekatan ini dipercaya akan secara signifikan mengurangi campur tangan pemerintah terhadap pasar. Melalui pendekatan ekonomi dan sukarela ini perbaikan lingkungan telah mengalami individualisasi.

Tulisan singkat ini mencoba melihat apakah RUU Jasa Lingkungan (selanjutnya disebut RUU Jasling) terpengaruh oleh semangat privatisasi ini atau RUU ini muncul murni karena keinginan untuk menginternalisasi biayabiaya lingkungan. Selanjutnya, tulisan ini juga akan mencoba melihat beberapa kekurangan yang terdapat pada naskah RUU (versi November 2008).

\section{Privatisasi Ekosistem?}

Dalam penjelasan umum RUU Jasling disebutkan bahwa pemulihan kerusakan mengalami beberapa kendala, salah satunya adalah kendala dalam hal pendanaan. Lebih jauh lagi, penjelasan umum ini juga melihat permasalahan utama dalam hal pendanaan adalah karena "...jasa lingkungan merupakan barang public (public goods) yang bersifat free-ride, open access, dan non-rivalry. Pemanfaatannya sangat bebas dan tidak terbatas sehingga menimbulkan tragedy of common [sic!]". ${ }^{3}$

\footnotetext{
${ }^{3}$ Menurut penulis, ketiga sifat yang disebutkan oleh penjelasan umum RUU Jasling ini sedikit rancu. Berdasarkan litertur yang penulis temukan, public goods ditandai oleh dua ciri, yaitu non-excludable dan non-rivalry. Untuk menjelaskan dua ciri ini, Prof. Kolstad menulis sebagai berikut. "A good is excludable if it is feasible and practical to selectively
} 
Solusi untuk mengatasi inefisiensi penggunaan SDA atau jasa lingkungan sesungguhnya terkait dengan cara pandang (ideologi) terhadap barang publik. Apabila public goods dan eksternalitas negative (negative externality) — dengan segala akibat buruknya berupa pencemaran, serta rusak dan habisnya SDA dan jasa lingkungan-dipandang sebagai bentuk kegagalan pasar (yaitu bahwa pasar tidak bisa berfungsi efisien), maka solusinya adalah campur tangan pemerintah. Pasar tidak boleh dibiarkan, tetapi harus diatur. Dengan demikian, menurut pandangan ini, Pemerintahlah yang berkewajiban untuk menyediakan barang publik ini dan membuat aturan untuk mengurangi eksternalitas negatif. Campur tangan ini bisa diwujudkan ke dalam beberapa instrumen, baik itu CAC (seperti penetapan standar, pengawasan, dan penjatuhan sanksi) atau pun penyediaan insenif dan disinsentif ekonomi (seperti pajak lingkungan atau sistem perdagangan izin). Di sisi lain, apabila public goods dianggap sebagai bentuk kegagalan pemerintah (government failure), maka solusinya adalah dengan menghapus barang publik tersebut dan menjadikannya barang privat. Pasar, dan bukan negara, yang berhak untuk mengurusi barang-barang ini.

Dalam prakteknya kita sering melihat di hampir semua negara di dunia, pemerintah turun tangan untuk menjamin ketersediaan mulai dari angkatan bersenjata dan polisi, sampai pada pelayanan kesehatan dan pendidikan, telekomunikasi dan energi. ${ }^{4}$ Di sisi lain, Pemerintah pun turun tangan secara aktif membuat berbagai regulasi lingkungan, mengawasi, dan kemudian memberikan sanksi pada mereka yang gagal untuk memenuhi kewajibannya berdasarkan aturan tersebut. ${ }^{5}$

allow consumers to consume the good", sedangkan " $A$ bad (good) is rival if one person's consumption of a unit of the bad (good) diminishes the amount of the bad (good) available for others to consume, i.e., there is a negative (positive) social opportunity cost to others associated with consumption. A bad (good) is nonrival otherwise.". Lihat: C.D. Kolstad, Environmental Economics (Oxford: Oxford University Press, 2000), hal. 78-82. Lihat juga misalnya: S. Estrin dan D. Laidler, "Introduction to Microeconomics", $4^{\text {th }}$ Edition (New York: Harvester Wheatsheaf, 1995), hal. 451-452. Dari penjelasan di atas, sebuah barang menjadi barang publik apabila konsumsi terhadap barang tersebut bisa dinikmati oleh semua orang (artinya semua orang memiliki akses yang sama untuk menikmati barang tersebut) dan pada sisi lain pemanfaatan barang tersebut oleh seseorang tidak akan mengurangi jatah konsumsi orang lain. Free ride bukanlah sifat dari barang publik. Istilah ini menjelaskan perilaku yang biasanya terjadi (dengan asumsi bahwa setiap orang memiliki sifat hanya mementingkan diri sendiri) pada barang publik.

${ }^{4}$ Lihat misalnya beberapa contoh yang diungkapkan oleh Mansfield, dalam: E. Mansfield, "Principles of Microeconomics", (New York: W.W. Norton \& Company, 1983), hal. 73-76. 
Dari contoh di atas dapat dilihat bahwa campur tangan pemerintah tidak terbatas pada penyediaan public goods yang bersifat non-excludable dan non-rivalry. Dalam banyak kasus, Pemerintah juga turun tangan memberikan berbagai pelayanan pada barang yang sesungguhnya tidak murni bersifat non-excludable dan non-rivalry. ${ }^{6}$ Light menyebutkan contoh bagaimana di Amerika Serikat pelayanan kesehatan dianggap bukan barang publik, sehingga pasien akan pergi ke dokter dan membayar sejumlah uang untuk keperluan pengobatannya, sama persis ketika ia membeli barang lainnya. Dengan demikian, mereka yang memiliki uang lebih dengan sendirinya akan memperoleh layanan kesehatan yang lebih baik pula. Sebaliknya di Kanada, layanan kesehatan dianggap sebagai barang publik, di mana semua warga negara berhak untuk memperoleh layanan kesehatan yang fasilitas dan staf-nya disediakan oleh negara. ${ }^{7}$ Atas dasar inilah maka Holmstrom menulis: "To a certain extent, what goods are public goods is a matter of decision. If the citizens in a society decide to provide a particular good, then it becomes a public good, even if critics argue that it could be satisfied better privately, on an individual basis. ${ }^{\prime 8}$

Keputusan untuk menetapkan apakah sebuah barang termasuk barang publik, terutama bagi barang-barang yang tidak sepenuhnya bersifat nonexcludable dan non-rivalry, dengan demikian sepenuhnya adalah keputusan politik, bukan keputusan atas dasar teori-teori ekonomi. Keputusan ini terkait dengan kehendak awal didirikannya sebuah negara, dengan kewajibankewajiban dasar yang harus dilakukan oleh negara untuk rakyatnya. Dengan demikian, teori tentang public goods erat kaitannya dengan cita-cita fungsi negara menurut faham negara kesejahteraan. Dan Indonesia, berdasarkan konstitusinya, telah memilih untuk membuat negara yang hanya berfungsi sebagai pelindung hak milik, tapi juga negara yang berfungsi untuk mensejahterakan dan melindungi rakyatnya (Pembukaan UUD 1945), negara

${ }^{5}$ Dalam hal ini, Prinsip 11 Deklarasi Rio menyatakan: "States shall enact effective environmental legislation. Environmental standards, management objectives and priorities should reflect the environmental and development context to which they apply".

${ }^{6}$ Light menyebut barang publik yang seperti ini sebagai "quasi-public goods", atau "publicly provided goods" (barang-barang yang disediakan secara publik), sebagai lawan dari "pure public goods", yaitu barang-barang yang benar-benar memenuhi kriteria nonexcludability dan non-rivalry. Lihat: A. Light, "Public Goods, Future Generations, and Environmental Quality", dalam: A. Anton, et al. (ed.), "Not for Sale: In Defense of Public Goods", (Oxford: Westview Press, 2000), hal. 212.

${ }^{7}$ Ibid., hal. 213-214.

${ }^{8}$ N. Holmstrom, "Rationality, Solidarity, and Public Goods", dalam: A. Anton, et al. (ed.), Not for Sale: In Defense of Public Goods (Oxford: Westview Press, 2000), hal. 79. 
yang menguasai sumber daya alam untuk kemudian dipergunakan bagi kesejahteraan rakyat (pasal 33 UUD 1945) dan negara yang melindungi fakir miskin dan menjamin pelayanan kesehatan bagi rakyatnya (pasal 34 UUD 1945).

Di sisi lain, aliran yang memandang fungsi negara sebagai penyedia barang-barang publik saat ini sedang mengalami kritik yang hebat, terutama dari kalangan neoliberal. Ferge menulis, dari sekian banyak tugas negara, fungsi negara yang terkait dengan kesejahteraan rakyatlah yang sekarang ini sedang dipreteli oleh faham neoliberlisme. ${ }^{9}$ Alih-alih membenarkan campur tangan negara untuk menyediakan public goods atau memperbaiki efektivitas pelaksanaan peran negara sebagai penyedia public goods, faham ini justru berupaya untuk menghilangkan public goods itu sendiri. Public goods justru dianggap sebagai ancaman terhadap privatisasi (karena public goods membenarkan adanya campur tangan negara ke dalam pasar), sebagai hambatan atas mobilitas kapital (karena modal yang ditanam untuk penyediaan public goods menjadi tidak profitable), sebagai kondisi yang membuat iklim investasi menjadi tidak kompetitif (karena public goods hanya bisa disediakan dengan adanya pajak yang tinggi, yang tentu saja sangat tidak disukai oleh para investor), atau sebagai sebuah sistem yang membatasi kontrol keuangan oleh pihak swasta (karena public goods dibiayai dan dikelola secara publik, dengan tujuan yang tidak semata-mata pencarian keuntungan). ${ }^{10}$ Pendek kata, public goods adalah bentuk ekonomi salah urus, inefisiensi dalam alokasi sumber daya.

Sepertinya, RUU Jasling menganut aliran yang terakhir ini. Ada paling tidak dua alasan yang bisa diajukan di sini.

${ }^{9}$ Menurut Ferge, fungsi negara dalam faham negara kesejahteraan dapat dilihat dari "civilizing functions", fungsi negara untuk membuat rakyatnya mampu hidup dan beradaptasi terhadap perubahan yang terjadi, dan "helping functions", yaitu fungsi yang terkait dengan peningkatan kesejahteraan rakyat. Penyediaan kesehatan dan pendidikan termasuk ke dalam "civilizing functions", sedangkan program redistribusi pendapatan dan pengentasan kemiskinan termasuk ke dalam "helping functions". Kedua fungsi inilah yang menurut Ferge hendak dihapuskan oleh faham neoliberalisme, yang menginginkan peran negara menjadi sangat minim, yaitu terbatas pada fungsi penjagaan keamanan dari luar (dan pada kondisi tertentu menjamin keamanan hak milik pribadi dan orang kaya di dalam "war against the poor". Lihat: Z. Ferge, "What are the State Functions that Neoliberalism Wants to Eliminate?", dalam: A. Anton, et al. (ed.), Not for Sale: In Defense of Public Goods, (Oxford: Westview Press, 2000), hal. 181-204.

${ }^{10}$ M. Fisk, "Surviving with Dignity in a Global Economy: The Battle for Public Goods", dalam: A. Anton, et al. (ed.), Not for Sale: In Defense of Public Goods, (Oxford: Westview Press, 2000), hal. 49. 
Pertama, RUU Jasling tegas-tegas menyatakan bahwa public goods akan membawa pada "tragedy of common". Penulis beranggapan bahwa para penyusun RUU Jasling tahu persis implikasi dari setiap istilah yang digunakan. Dalam hal ini, penggunaan istilah "tragedy of common" bukanlah tanpa alasan.

Istilah "the tragedy of the commons" merupakan istilah yang lazim digunakan untuk merujuk pada hancurnya SDA sebagai akibat dari dimasukannya SDA sebagai barang publik, terutama setelah istilah ini digunakan oleh Garrett Hardin dalam tulisannya "The Tragedy of the Commons" pada jurnal ilmiah Science pada tahun 1968." Dalam tulisan ini, Hardin memberikan contoh pemakaian sebuah barang publik berupa padang rumput oleh para peternak. Dengan asumsi bahwa setiap orang memiliki sifat self-interest dan profit maximizing, Hardin berpendapat bahwa orang yang rasional justru akan memanfaatkan padang rumput tersebut untuk keuntungan pribadi yang sebesar-besarnya. Apabila setiap peternak berpikir rasional seperti ini, maka mereka hanya memikirkan bagaimana memanfaatkan sumber daya alam (SDA) atau jasa lingkungan tanpa peduli bahwa pemanfaatan yang berlebihan itu akan mengarah pada kehancuran. Semuanya hanya mau menjadi free-rider, penumpang gelap, dari usaha perbaikan SDA atau jasa lingkungan yang dilakukan oleh orang lain. Akibatnya, padang rumput tersebut akan mengalami overexploitation.

Lalu apa solusinya? Hardin menyatakan:

"We might sell them off as private property. We might keep them as public property, but allocate the right to enter them. The allocation might be on the basis of wealth, by the use of an auction system. It might be on the basis of merit, as defined by some agreed-upon standards. It might be by lottery. Or it might be on a first-come, first served basis, administered to long queues". ${ }^{2}$

Dengan demikian, solusi atas kerusakan SDA sebagai sebuah barang publik adalah dengan jalan privatisasi atas barang tersebut. Caranya memang bermacam-macam, tapi tujuannya satu: mengubah sifat barang publik dari yang tadinya non-excludable dan non-rivalry menjadi barang yang hanya

1248.

${ }^{11}$ G. Hardin, 1968, "The Tragedy of the Commons", Science, Vol. 162, hal. 1243-

${ }^{12}$ Ibid., hal. 1245 . 
bisa dinikmati oleh mereka yang memiliki uang untuk menguasai barang tersebut.

Kedua, jejak-jejak semangat privatisasi juga tampak terlihat dari institusi yang ingin dibangun oleh RUU Jasling. Pada awalnya dibentuk Komite Pengelola Jasa Lingkungan (KPJL) di pusat dan daerah, yang sifatnya mandiri, terlepas dari Pemerintah, dengan wewenang seperti diatur dalam 11. KPJL ini hanya bertanggung jawab kepada Presiden, tapi tidak kepada pemerintah daerah (untuk KPJL di tingkat daerah). Kemudian, pasal 29-33 menyatakan bahwa perencanaan, pelaksanaan, bahkan pengawasan atas pelaksanaan tata kelola jasa lingkungan akan dilakukan oleh pihak ketiga (baca: swasta!). Dalam hal pengolaan dana, RUU memberikan kewenangan ini kepada sebuah bank atau lembagai keuangan khusus, yang pada saat tertentu bisa beroperasi secara komersial (pasal 41).

Privatisasi pengelolaan jasa lingkungan, menurut penulis, haruslah ditolak. Pada satu sisi, privatisasi ini inkonstitusional. Tidak sesuai dengan semangat negara kesejahteraan yang diamanatkan oleh konstitusi kita. Di sisi lain, secara teoritis, pendapat Hardin pun telah banyak dibantah. Tidak selamanya barang publik akan mengarah pada kehancuran. ${ }^{13}$ Solusi dari kehancuran/penipisan SDA dan jasa lingkungan, bukanlah dengan jalan privatisasi SDA dan jasa lingkungan, tapi justru dengan menegaskan kembali bahwa SDA dan jasa lingkungan adalah milik bangsa Indonesia. Karenanya,

${ }^{13}$ Shiva secara brilian menunjukkan bahwa "the commons" bukanlah sesuatu yang tidak ada pemiliknya. Sebaliknya barang ini, the commons, ada pemiliknya, yaitu komunitas, rakyat, atau bangsa. Masyarakatlah yang akan menentukan seberapa banyak barang tersebut dapat dikonsumsi, atau dengan cara apa pemanfaatan atas barang tersebut dilakukan. Bagi banyak masyarakat adat, lingkungan hidup sebagai the commons bukanlah barang tak bertuan (terra nullius), tapi justru barang kepunyaan bersama (terra communis). Alam dihormati bukan karena ia milik individu. Dalam beberapa komunitas adat, alam dihormati justru karena dialah yang memiliki kita, yang menyebabkan kita ada. Alam adalah terra mater, mother earth. V. Shiva, Earth Democracy: Justice, Sustainability, and Peace, (Cambridge, MA: South End Press, 2005), hal. 21-24. Pendapat yang sama juga diajukan oleh Common dan Stagl. Menurut mereka istilah "common goods" atau "common property", harus dibedakan dari istilah "open access". Apabila lingkungan hidup atau alam dipandang sebagai "common property", maka lingkungan hidup atau alam bukannya tidak ada yang memiliki. Dalam pandangan ini, masyarakatlah yang secara bersama-sama menjadi pemilik dari alam atau lingkungan hidup. Sedangkan istilah "open access" justru bermakna bahwa lingkungan hidup atau alam terbuka bagi siapa saja untuk memanfaatkannya, karena tidak ada yang memilikinya (tanah tak bertuan). "Open access". karenanya, tidak menunjukkan adanya "common property", tapi justru menunjukkan "no property" Teori Hardin tentang "the tragedy of the commons" telah mencampuradukkan kedua istilah ini dengan menganggap bahwa "open access" sama dengan "public goods" Dan "no property". tanah tak bertuan, inilah yang lebih mungkin akan mengarah kepada tragedi atau kehancuran. M. Common dan S. Stagl, "Ecological Economics: an Introduction". (Cambridge: Cambridge University Press, 2005), hal. 337-339. 
pemerintah bersama-sama dengan rakyatnya, bertanggung jawab atas kelestarian dari barang milik bangsa tersebut.

\section{Melihat dari Dekat Pendekatan Ekonomi atas Penaatan Lingkungan}

Meskipun telah sering kali dibicarakan, pendekatan ekonomi dalam pengelolaan lingkungan masih sangat terbatas. Hal ini sesungguhnya tidak perlu terjadi, sebab pasal 10 UU No. 23 tahun 1997 tentang pengelolaan lingkungan hidup telah memberikan wewenang kepada Pemerintah untuk mengembangkan kebijakan berdasarkan insentif dan disinsentif. Meski demikian, pendekatan ekonomi telah sering salah kaprah diartikan oleh beberapa kalangan. Pendekatan ini sering dianggap sebagai bagian dari pendekatan sukarela atau perilaku (moral suasion), sehingga pendekatan ekonomi dianggap sebagai lawan dari CAC hanya karena pendekatan ekonomi dianggap sebagai upaya yang menghilangkan campur tangan pemerintah. Berbeda dari pandangan ini, penulis beranggapan bahwa campur tangan pemerintah di dalam pendekatan ekonomi sangatlah besar, jika tidak ingin dikatakan merupakan hal yang sentral.

Pendekatan ekonomi berawal dari prinsip pencemar membayar (polluter pays principle). Dalam pandangan ekonom, pencemaran merupakan bentuk dari kegagalan pasar (market failures) yang memungkinkan adanya intervensi negara ke dalam kegiatan-kegiatan ekonomi (pasar). Kegagalan pasar dalam bentuk pencemaran merupakan akibat dari diabaikannya biayabiaya lingkungan di dalam keputusan individu, sehingga pencemaran dalam ilmu ekonomi ditandai dengan adanya perbedaan "private costs" dengan "social costs". ${ }^{14}$ Oleh para ekonom, pencemara dianggap muncul karena absenya pasar (tidak ada pertukaran melalui supply and demand) atau karena absennya harga pasar untuk jasa dan sumber daya lingkungan, baik sebagian atau seluruhnya. ${ }^{15}$ Akibatnya, harga dari barang jarang sekali secara utuh merefleksikan harga yang diperlukan untuk membuat barang tersebut, karena harga jasa dan sumber daya lingkungan, serta harga pencemaran jarang sekali dipertimbangkan dalam pengambilan keputusan individu. Akibatnya, industri atau bahkan individu, akan melakukan kegian mereka untuk mencapai

${ }^{14}$ EE.J. Solberg, "Intermediate Microeconomics", (Texas: Business Publication, 1982), p. 540 .

15 B. Groosman, "Pollution Tax" in B. Bouckaert and G. de Geest (ed.), Encyclopedia of Law and Economics Volume II: Civil Law and Economics, (Cheltenham: Edward Elgar, 2000), hal. 539. 
sebesar mungkin keuntungan pribadi, tanpa mempertimbangkan ongkos yang ditanggung oleh masyarakat. Dengan asumsi ini, maka campur tangan pemerintah dalam bentuk hukum atau kebijakan lingkungan terutama diarahkan sebagai upaya internalisasi terhadap eksternalitas biaya-biaya lingkungan tersebut. ${ }^{16}$ Dengan membuat pencemar membayar pencemaran yang diakibatkannya, maka para pencemar tersebut dipaksa untuk melakukan internalisasi eksternalitas, yang pada akhirnya akan mencegah munculnya kegagalan pasar. ${ }^{17}$

Adapun instrumen yang dapat digunakan melalui instrumen ekonomi ini adalah: ${ }^{18}$

\section{Pajak lingkungan}

Ide dari pajak lingkungan berawal dari Pigou, yang menyatakan bahwa pencemaran dapat diatasi dengan mengenakan pajak bagi setiap kegiatan yang menimbulkan pencemaran. Dengan adanya pajak, maka harga produk (yang dikenakan pajak) akan menjadi lebih mahal. Perubahan harga ini akan menyebabkan bergesernya kurva permintaan, yang menunjukkan semakin berkurangnya permintaan akan produk tersebut. Dengan demikian maka akan tercipta ekuilibrium baru yang mencerminkan penawarandan dan permintaan yang sesuai dengan biaya marjinal sosial. Secara sederhana maka dapat dikatakan bahwa pajak akan mendorong

10.

${ }^{16}$ M. Faure, 2001, "Environmental Law and Economics", METRO, Maastricht, hal.

${ }^{17}$ R.K. Turner, D. Pearce, and I. Bateman, 1994, Environmental Economics: an Elementary Introduction, (New York: Harvester Wheatsheaf), hal. 77. Perlu pula diketahui bahwa penggunaan internalisasi biaya lingkungan dan efisiensi sebagai landasan teoritis bagi kebijakan lingkungan (yaitu sebagai alat untuk membenahi kegagalan pasar) telah banyak ditentang oleh berbagai pengarang. Sagoff, misalnya, berpendapat bahwa kebijakan lingkungan dapat dibenarkan bukan atas dasar pendekatan ekonomi yang melihat sumber daya lingkungan hanya sebatas komoditas, tapi atas dasar nilai (values) terkait dengan kesehatan, keamanan, rasa estetika, dan penghargaan atas lingkungan hidup. Lihat: M. Sagoff, "The Economi of the Earth: Philosophy, Law, and the Environment", (Cambridge: Cambridge University Press, 1996), hal. 7-17.

18 D.W. Pearce dan R.K. Turner, "Economics of Natural Resources and the Environment", (Baltimore: the Johns Hopkins University Press, 1990), hal. 159-176. Pembahasan mengenai jenis-jenis dan penerapan instrument ekonomi dapat ditemui di dalam berbagai literatur lainnya, seperti: D.J. Dudek, R.B. Stewart, dan J.B. Wiener, "TechnologyBased Approaches versus Market-Based Approaches", dalam P. Sands (ed.), Greening International Law, (London: Earthscan Publications, 1993), hal. 182-209; B. Greenwood, "Looking Ahead: Environmental Regulation: A Future", dalam: A.E. Boyle, Environmental Regulation and Economic Growth, (Oxford: Oxford University Press, 1994), hal. 99-130. 
harga barang yang tidak ramah lingkungan menjadi lebih mahal dari pada yang ramah lingkungan, sehingga pada akhirnya semua orang akan terdorong untuk melakukan produksi yang ramah lingkungan.

Jenis dari pajak lingkungan yang lazim dikenal antara lain: ${ }^{19}$

a) pajak atau charges bagi biaya-biaya adminstrasi untuk melaksanakan sistem peraturan. Hal ini dilakukan misalnya dengan mengenakan charges bagi biaya yang diperlukan untuk pengeluaran izin, serta untuk membiayai inspeksi, pengawasan, dan monitoring implementasi isi dari izin tersebut.

b) Pajak atau charges yang dikenakan untuk pelaksanaan pengawasan lingkungan dan penanggulangan pencemaran. Charges jenis ini di samping terkait dengan tindakan preventif (berupa pengawasan) juga terkait dengan denda yang diperuntukkan sebagai biaya pembersihan setelah terjadinya pencemaran.

c) Pajak atau charges yang mencerminkan biaya lingkungan total dari kegiatan yang tertentu. Pajak ini seringkali dikaitkan dengan tingkat emisi yang dihasilkan, sehingga seringkali juga disebut sebagai emission charges $^{20}$. Contoh dari pajak ini ialah Carbon Tax yang diterapkan pada setiap pemakaian bahan bakar yang mengandung karbon.

d) Pajak atau charges yang dikenakan bagi setiap penggunaan bahan atau proses yang dapat menimbulkan pencemaran. Menurut Greenwood, charges jenis ini disebut sebagai Product charges, yaitu charges yang dikenakan pada produk-produk yang, ketika digunakan dalam proses produksi, dikonsumsi dan dibuang, berbahaya bagi lingkungan. ${ }^{21}$ Jenis dari pajak ini dapat dilihat pada landfill tax, yaitu pajak yang dibebankan pada pengelola limbah, yang akan mendorong naikknya biaya pengelolaan limbah, sehingga pada akhirnya akan

19 S. Bell dan D. McGillivray, "Environmental Law", 5th edition, (London: Blackstone Press, 2000), hal. 201-204.

${ }^{20}$ Brian Greenwood, "Looking Ahead: Environmental Regulation-A Future?" dalam Environmental Regulation and Economic Growth, (Alan Boyle, ed.), (Oxford: Oxford University Press, 1994), hal. 116.

${ }^{21}$ Loc. Cit. 
mendorong orang untuk menggunakan barang yang menghasilkan limbah sedikit.

Keunggulan dari pajak ialah kemampuannya untuk secara langsung menginternalkan biaya-biaya lingkungan, sehingga kegiatan yang tidak ramah lingkungan secara langsung akan terdoorong untuk segera berubah menjadi kegiatan yang ramah lingkungan. Meskipun demikian, ada beberapa hal yang perlu diperhatikan dalam penerapan pajak lingkungan. ${ }^{22}$ Pertama, pajak harus memiliki keterkaitan dengan target kualitas lingkungan yang ingin dicapai. Penetapan besaran pajak karenanya merupakan hal yang paling menentukan dalam penerapan pajak lingkungan. Apabila pajak terlalu rendah (kurang optimal), maka pajak lingkungan tidak akan memberikan insentif yang memadai bagi upaya internalisasi eksternalitas, dan akibatnya kegiatan yang mencemari menjadi tidak mengalami penurunan yang signifikan. ${ }^{23}$ $K e d u a$, pajak lingkungan harus memiliki kaitan yang erat dengan emisi. Semakin tinggi kaitan antara pajak dengan emisi, maka semakin efektiflah penerapan pajak lingkungan. Persoalannya, emisi bukanlah sesuatu yang mudah untuk diawasi, yang bahkan seringkali kali merupakan gabungan dari berbagai jenis polutan. ${ }^{24}$ Jika ini terjadi, maka pelaksanaan pajak lingkungan akan

${ }^{22}$ Catatan ini dapat dilihat pada: J.P. Barde, "Environmental Policy and Policy Instruments", dalam: H. Folmer, H.L. Gabel, dan H. Opschoor (eds.), "Principles of Environmental and Resource Economics: A Guide for Students and Decision-Makers", (Aldershot: Edward Elgar), hal. 235-236; dan: R.K. Turner, D. Pearce, dan I. Bateman, "Environmental Economics: an Elementary Introduction", (New York: Harvester Wheatsheaf, 1994), hal. 173-175.

${ }^{23}$ Sayangnya, bahkan penerapan pajak di negara maju pun tidak terlepas dari kegagalan ini. Perman, et al., menyatakan bahwa praktek di negara maju menunjukkan dampak dari pajak lingkungan relatif rendah, sebagai akibat dari pajak yang terlalu rendah. Perman, et al., menyatakan bahwa keberhasilan pajak lingkungan salah satunya ditentukan oleh penetapan pajak yang tinggi, seperti pada kasus pajak air di Belanda. Hal senada juga diutarakan oleh Oates dan Baumol. Menurut mereka, pajak yang tinggi memiliki dua akibat yang positif. Di satu sisi, pajak yang tinggi ini akan menurunkan resiko munculnya pencemaran. Di sisi lain, turunnya resiko pencemaran berarti turunnya pula kebutuhan untuk melakukan pengawasan. Lihat: Perman, et al., "Natural Resources and Environmental Economics", 2nd ed (Essex: Longman, 1999), hal. 222-223; dan W. Oates dan W. Baumol, "Instrument for Environmental Policy", dalam: W.E. Oates (ed.). The Economics of Environmental Regulation, (Cheltenham: Edward Elgar, 1996), hal. 110.

${ }^{24}$ Oates dan Baumol misalnya menyatakan bahwa pajak yang diterapkan untuk limbah cair harus memperhatikan tingkat BOD, kandungan polutan yang tidak bisa terturai, suhu, dan mungkin volume dari limbah cair tersebut. W. Oates W. Baumol, ibid., hal. 104. 
membutuhkan biaya pengawasan yang sangat besar, sedang di sisi lain akan membuat pelaku usaha berada dalam "lautan pajak". ${ }^{25}$ Ketiga, pajak lingkungan dapat bersifat regresif, dalam artian bahwa pajak dapat memberikan efek yang lebih besar terhadap pendapatan orang yang kurang mampu, dibandingkan terhadap efek pada mereka yang kaya. Dengan demikian, pajak lingkungan memiliki kendala politis yang besar untuk dapat diterapkan. Keempat, efektifitas pajak lingkungan (terutama product charges) bergantung pada keberadaan barang substitusi (atau kurva elastisitas permintaan). Apabila permintaan bersifat inelastis (yang artinya tidak ada barang substitusi atas barang yang dikenai pajak), maka pajak lingkungan atas sebuah barang yang berpotensi mencemari tidak akan memiliki dampak yang signifikan.

2. Sistem Pengembalian Deposit (Deposit Refund System)

Pada sistem ini, seseorang harus membayar di muka sejumlah uang sebagai jaminan bahwa ia tidak akan melakukan pencemaran atau bahwa ia telah melakukan kegiatan tertentu yang diwajibkan kepadanya. Pada akhir kegiatannya, uang jaminan tersebut akan dikembalikan kepadanya. Contoh dari sistem ini ialah adanya Dana Jaminan Reklamasi, yang mewajibkan para pengusaha tambang di Indonesia untuk membayar sejumlah uang jaminan, yang akan dikembalikan begitu pengusaha tersebut telah selesai melakukan seluruh program reklamasi (suatu kegiatan untuk memulihkan kondisi di daerah pertambangan tertentu setelah kegiatan pertambangan di daerah tersebut berakhir). Contoh

\footnotetext{
${ }^{25}$ Untuk menghindari kesulitan ini, terdapat beberapa alternatif penerapan pajak lingkungan. Alternatif pertama ialah dengan jalan menggabungkan beberapa jenis polutan sebagai dasar penerapan pajak (assessment base), seperti diterapkan dalam pajak air di Jerman, Perancis, dan Belanda, atau pajak pencemaran udara untuk industri di Latvia dan RRC. Alternatif lainnya ialah dengan menerapkan indikator polutan yang tidak langsung (misalnya sulfur digunakan sebagai indikator bagi penerapan pajak bahan bakar (carbon tax) atau penerapan pajak yang sama bagi semua pencemar (flat rate). Lihat: R.N. Stavins, 2003, "Experience with Market-based Environmental Policy Instruments", dalam K.G. Mäler dan J.R. Vincent (eds.), Handbook of Environmental Econmics Volume I: Environmental Degradation and Institutional Responses, (Amsterdam:Elsevier), hal. 262-272; dan S. De Kock, "Government Financial Incentive for the Protection of the Environment", dalam: M. Bothe (ed.), "Trends in Environmental Policy and Law", (Gland: IUCN, 1980), hal. 64 dan 67. Alternatif lainnya ialah menerapkan pajak kepada input pencemaran, dan bukannya pada output (emisi). Hal ini misalnya dapat dilihat pada carbon tax di mana pajak dibebankan kepada setiap liter bensin (input), dan bukannya pada emisi karbon dari tidap kendaraan/pabrik. Alternatif inilah yang mungkin paling efektif dan murah, karena alternatif ini bahkan tidak membutuhkan adanya pengawasan yang diperlukan untuk mengukur emisi.
} 
lainnya ialah pengembalian uang yang terjadi apabila kita mengembalikan botol minuman kepada tempat-tempat tertentu. Sistem ini mendorong terjadinya reuse, recycle, dan pembuangan sampah secara aman, karena dengan sistem ini maka pembuangan sampah menjadi tidak lagi menguntungkan.

Penetapan uang jaminan atas kegiatan tertentu selayaknya mempertimbangkan beberapa aspek, seperti diutarakan oleh Costanza dan Perrings. Pertama, penetapan jumlah uang jaminan harus terkait dengan tingkat ilmu pengetahuan yang ada. Ini berarti besaran uang jaminan dan waktu penetapannya akan berbeba-beda tergantung dari apakah sebuah kegiatan akan berlangsung lama atau singkat. Untuk kegiatan yang berlangsung lama, maka uang jaminan dapat ditetapkan secara sekuensial. Kedua, waktu pengembalian uang jaminan harus memiliki kaitan dengan sifat pencemaran, yaitu apakah pencemaran sulit dihilangkan atau tidak (rate of decay). Semakin tinggi rate of decay dari polutan, maka semakin cepat uang jaminan dapat dikembalikan. Ketiga, besaran uang jaminan dan waktu pengembaliannya harus ditetapkan dengan mempertimbangkan skenario pencemaran yang terburuk (the worst case scenario). Ini berarti bahwa permormance bond terkait erat dengan tingkat pengetahuan dan proses pembelajaran, sehingga ia haruslah bersifat fleksibel terhadap perubahan ilmu pengetahuan dan kondisi lingkungan. ${ }^{26}$ Terkait dengan aspek terakhir ini, Costanza dan Cornwell mengusulkan agar performance bond diterapkan berdasarkan asas kehati-hatian. Artinya, uang jaminan ditetapkan tidak hanya berdasarkan pada kerusakan yang sudah bisa diprediksi secara pasti, tapi juga berdasarkan kerusakan yang meskipun secara ilmiah belum konklusif tetapi dapat menimbulkan dampak yang serius dan tidak bisa dipulihkan. Dengan penerapan uang jaminan seperti ini, maka para pengguna sumber daya lingkungan lah (para calon pencemar) yang memiliki bebab untuk membuktikan bahwa kegiatan mereka tidak akan menimbulkan dampak seperti yang dikhawatirkan. Constanza dan Cornwell menyebut uang jaminan seperti ini sebagai "the precautionary polluter pays principle". ${ }^{27}$

${ }^{26}$ R. Costanza dan C. Perrings. "A Flexible Assurance Bonding System for Improved Environmental Management". Ecological Economics. 1990. Vol. 2. hal. 66. 


\section{Izin yang Dapat Diperjualbelikan (Tradeable Permit)}

Dalam sistem ini, pertama-tama pemerintah menetapkan adanya ambang batas pencemaran di daerah tertentu. Berdasarkan ambang batas ini, pemerintah kemudian mengeluarkan izin (untuk 'mencemari'), yang masing-masing izin ini mempunyai ambang batasnya sendiri. Pada tahap awal, izin ini diberikan kepada pengusaha melalui lelang, sehingga dapat saja suatu perusahaan memiliki beberapa izin. Dalam perkembangannya, perusahaan yang mampu mengurangi tingkat pencemaran kurang dari ambang batas yang ditetapkan dalam izin akan memperoleh keuntungan ekonomi, karena ia dapat menjual izin tersebut kepada mereka yang memerlukannya (yaitu mereka yang emisinya melampaui batas yang ditetapkan di dalam izin). Di sini terlihat bahwa semakin besar pengurangan pencemaran, maka semakin besar keuntungan ekonomi yang diperoleh. Di sini, situasi di sebuah perusahaan bahkan bisa jauh lebih baik dari pada yang diperbolehkan oleh standar.

Tentu saja sistem ini memerlukan pengawasan yang sangat ketat dari pemerintah, sehingga justru memerlukan biaya administrative yang besar.

Persoalan penting yang perlu dipertimbangkan dalam penerapan jual-beli izin ini adalah pengalokasian izin dan penetapan harga pertama kali. Pada prinsipnya, harga tiap izin (yang berarti pula kuota emisi) ditetapkan berdasarkan lelang (auction). Berdasarkan lelang ini, maka kuota emisi akan diberikan pada mereka yang paling tinggi menilai emisi tersebut (atau dengan kata lain, mereka yang berani membayar mahal untuk emisi yang dihasilkannya). Jika ini terjadi, maka penetapan kuota dapat dikatakan telah memenuhi syarat "allocative efficiency". Akan tetapi, pada prakteknya, kuota emisi pertama justru dilakukan berdasarkan "grandfathering", yaitu pemberian kuota kepada para pencemar saat ini (incumbent), yang seringkali dilakukan bahkan sedikit sewenang-wenang. Hal ini dapat menimbulkan efek yang buruk pada efektivitas instrumen perdagangan izin ini. Di satu sisi, grandfathering seperti memberikan pembenaran pada para pencemar terhadap pencemaran yang telah dan akan mereka lakukan. Dalam hal ini, yang menjadi dasar pertimbangan utama dari grandfathering adalah kepentingan dan kemampuan para pencemar, bukannya perlindungan masyarakat dan lingkungan

${ }^{27}$ R. Costanza dan L. Cornwell, "The 4P Approach to Dealing with Scientific Uncertainty", Environment, 1992, Vol. 34, No. 9. 
secara umum. Di sisi lain, grandfathering juga dapat berfungsi sebagai alat yang digunakan oleh perusahaan pencemar untuk menghambat calon kompetitor mereka (barrier to enter) ${ }^{28}$

4. Subsidi

Subsidi merupakan kebalikan dari pajak. Pada prinsipnya keadaan yang ingin dicapai tidak berbeda dengan pajak, yaitu bahwa barang yang ramah lingkungan menjadi lebih murah dari pada yang tidak ramah lingkungan. Meski demikian, subsidi dikritik karena ia tidak akan mendorong para pengusaha untuk memperbaiki sistem produksinya menjadi lebih bersih, karena semua biaya lingkungan akan ditanggung oleh pemerintah. Di samping itu, subsidi juga dikritik karena sistem ini justru memberikan dana bagi para pencemar, dan bukannya memaksa para pencemar untuk bertanggungjawab atas pencemaran yang terjadi.

Meskipun bertujuan sama, yaitu memberikan dorongan ekonomi bagi upaya internalisasi eksternalitas, pajak dan subsidi tentu saja memiliki perbedaan yang mendasar. Pertama, pajak bekerja dengan memberikan disinsentif pada kegiatan yang mencemari. Semakin besar pencemaran yang dilakukan, sebuah banyak pajak yang harus dibayar. Sebaliknya, semakin ramah lingkungan sebuah kegiatan, maka semakin kecil pajak yang harus dibayar. Sedangkan subsidi bekerja dengan jalan memberikan insentif pada pelaku kegiatan untuk melakukan upaya-upaya pencegahan pencemaran atau perbaikan lingkungan. Kedua, subsidi dan pajak akan mencapai hasil yang berbeda apabila kita melihat perusahaan-perusahaan dalam satu industri. Subsidi memang dapat memberikan dorongan bagi tiap perusahaan untuk menurunkan emisinya. Akan tetapi, penurunan emisi tiap perusahaan tidak serta merta berarti adanya penurunan emisi industri, karena subsidi, berbeda dengan pajak, justru memberikan menarik perusahaan-perusahaan lain untuk masuk ke dalam industri yang sama. Akibatnya, meski emisi tiap perusahaan berkurang, emisi industri belum tentu akan berkurang. ${ }^{29}$ Ketiga, subsidi dan pajak memiliki perbedaan secara filosofis. Dalam

${ }^{28}$ A. Ogus, "Nudging and Rectifying: the Use of Fiscal Instruments for Regulatory Purposes", Legal Studies, 1999, Vol. 19, hal. 169.

${ }^{29}$ K.G. Löfgren, "Market and Externalities", in: H. Folmer, H.L. Gabel and H. Opschoor (eds.), "Principles of Environmental and Resource Economics: A Guide for Students and Decision-Makers", (Aldershot: Edward Elgar, 1995), hal. 26. 
pajak, pencemar diharuskan membayar, sebagai bentuk dari internalisasi eksternalitas. Dalam subsidi, justru pencemar-lah yang dibayar oleh negara. Karena uang negara sebagian berasal dari masyarakat luas, yang notabene adalah korban pencemaran, maka subsidi mengindikasikan adanya penyimpangan terhadap asas pencemar membayar. Sebaliknya, yang berlaku pada subsidi mungkin adalah "victims pay principle".

Untuk selanjutnya, contoh penerapan instrumen ekonomi di negara lain dapat dilihat pada lampiran dari tulisan ini.

Dalam menerapkan instrumen ekonomi, terdapat beberapa catatan yang patut untuk dipertimbangkan. Pertama, instrumen ekonomi berbeda dengan penaatan sukarela. Oates dan Baumol secara jelas membedakan antara instrumen ekonomi (yang didasarkan pada adanya pemberian insentif ekonomi bagi upaya perlindungan lingkunan) dan penaataan sukarela (yang didasarkan pada ketiadaan penegakan hukum, sehingga penaatan menjadi keputusan individual yang bersifat sukarela). ${ }^{30}$ Senada dengan pendapat ini, Faure, et.al., menyatakan bahwa instrumen ekonomi dilandaskan pada dua hal, yaitu: di satu sisi, instrumen ini didasarkan pada penciptaan dorongan yang bersifat ekonomis atas penaatan; sedang di sisi lain instrumen ini dilandaskan pada kebebasan pencemar (untuk menentukan tingkat pencemaran mereka dan bagaimana mereka mencapai tingkat pencemaran tersebut). ${ }^{31} \mathrm{Kedua}$, instrumen ekonomi tidak ditujukan sebagai upaya untuk mengurangi atau menghapuskan peranan pemerintah dalam perlindungan lingkungan. Sebaliknya, instrumen ekonomi justru mensyaratkan adanya campur tangan pemerintah dari mulai pengaturan, perizinan (tradeable permits mengharuskan adanya izin bagi tindakan pencemara. Hanya mereka yang memiliki izin lah yang memiliki "hak" untuk melepaskan emisinya), penetapan harga (terutama dalam penetapan tax rate), sampai pada pengawasan (baik pajak, performance bond, maupun tradeable permits mengharuskan adanya pengawasan dari pemerintah). Dengan demikian, berbeda dengan penaatan sukarela, di dalam instrumen ekonomi pemerintah memiliki peran yang sangat sentral. Ketiga, tujuan utama dari instrumen ekonomi adalah internalisasi eksternalitas, dan bukan peningkatan pendapatan negara. Efektifnya sebuah instrumen ekonomi, misalnya pajak

${ }^{30}$ W. Oates dan W. Baumol, Op. Cit., hal. 96-98.

${ }^{31}$ M. Faure, M. Peeters, dan A.G. Wibisana, "Economic Instruments: Suited to Developing Countries?", dalam M. Faure dan N. Niessen (eds.), "Environmental Law in Development: Lessons from the Indonesian Experience", (Cheltenham: Edward Elgar, 2006), hal. 219. 
lingkungan, justru bisa dilihat dari semakin menurunnya pendapatan negara dari pajak lingkungan, karena hal ini menandakan bahwa pelaku usaha/kegiatan telah mengubah perilaku atau proses kegiatan mereka menjadi ramah lingkungan.

Seharusnya, apabila benar-benar berkeinginan untuk menerapkan pendekatan ekonomi, seperti terlihat di dalam Naskah Akademik RUU Jasling, RUU Jasling memuat beberapa instrumen yang biasa digunakan untuk mendorong terjadinya internalisasi biaya lingkungan. Sayangnya, RUU Jasling sebenarnya hanya memuat satu instrumen ekonomi saja, yaitu "user charge", yaitu beban keuangan yang diberikan kepada pengguna atau pemanfaat lingkungan atau jasa lingkungan. Undang-undang lain, seperti UUPLH 1997 dan UU Energi 2007, justru memungkinkan adanya penerapan instrumen ekonomi yang lebih luas dari pada sekedar "user charge" seperti yang diusulkan oleh RUU Jasling. ${ }^{32}$ Dengan keterbatasan instrumen ini, penulis menyangsikan bahwa materi RUU ini adalah materi muatan sebuah undang-undang.

Jika dilihat dari instrumennya materi RUU Jasling lebih merupakan materi peraturan pemerintah, dibandingkan dengan materi undang-undang, lalu materi apa yang membuat RUU Jasling ini layak menjadi undangundang? Atas pertanyaan ini, penulis beranggapan system pengelolaan, yang kemudian memunculkan lembaga (swasta) yang khusus bertindak sebagai pengelola jasa lingkungan, sebagai satu-satunya materi baru yang membuat persoalan pengelolaan jasa lingkungan diatur di dalam sebuah undangundang. Jika ini yang terjadi, munculnya RUU Jasling bukan didorong oleh kebutuhan untuk menginternalisasi biaya-biaya lingkungan atau untuk mengembangkan instrumen ekonomi dalam pengelolaan lingkungan, tetapi didorong oleh semangat privatisasi pengelolaan jasa lingkungan.

\section{Persoalan lain dari RUU Jasa Lingkungan}

Di samping beberapa hal yang telah disebutkan pada bagian-bagian sebelumnya, RUU Jasling dapat pula dikritik atas beberapa konsep yang dimuat di dalamnya. Penulis menemukan paling tidak empat kerancuan konsep di dalam RUU Jasling, yaitu:

1. Pemanfaatan jasa lingkungan yang terkena kewajiban kompensasi diartikan terlalu sempit

${ }^{32}$ Anehnya, Naskah Akadmik RUU Jasling beberapa kali justru memuat pentingnya penerapan berbagai instrumen ekonomi untuk mencegah dan menurunkan eksternalitas. 
Pasal 8 ayat 1 RUU Jasling menyatakan bahwa yang dimaksud dengan jasa lingkungan adalah: "sumber daya yang dihasilkan oleh ekosistem yang dikelola oleh penyedia dan memberikan manfaat ekonomi bagi pemanfaat." Definisi ini dapat berarti sangat luas karena semua hal yang dihasilkan oleh alam dapat diartikan sebagai bermanfaat secara ekonomi, tergantung dari seberapa jauh frase "manfaat ekonomi" akan diartikan. Mengingat hal ini, maka ayat 2 dari pasal 8 kemudian membatasi apa saja yang oleh RUU Jasling dianggap sebagai jasa lingkungan yang memberi "manfaat ekonomi".

Pola yang sama juga terlihat dari makna pemanfaatan jasa lingkungan. Menurut pasal 10 ayat 1 RUU Jasling, "pemanfaat jasa lingkungan adalah orang dan/atau badan yang memperoleh keuntungan ekonomi atas penggunaan jasa lingkungan." Lagi-lagi kita berhadapan dengan definisi terlalu luas, tergantung dari sejauh mana "keuntungan ekonomi" akan diartikan. Oleh karena itu, RUU Jasling juga membatasi pengertian pada ayat 1 dengan memberikan daftar kegiatan yang dapat dianggap sebagai pemanfaatan jasa lingkungan (pasal 2).

Meskipun pembuatan daftar seperti ini dapat memberikan kejelasan pada makna yang luas, tetapi daftar tersebut juga memiliki kelemahan karena bisa saja daftar yang dibuat menjadi terlalu sempit. Dan hal ini sepertinya dialami pula oleh RUU Jasling.

Mengingat bahwa pemanfaat jasa lingkungan adalah mereka yang berkewajiban membayar "kompensasi", menjadi aneh bahwa kegiatan di sektor kehutanan dan pertambangan, yaitu sektorsektor yang tidak hanya memanfaatkan jasa lingkungan, tapi juga paling banyak menghilangkan, kalau bukan merusak, jasa lingkungan malah tidak termasuk ke dalam daftar para pemanfaat jasa lingkungan. Sebaliknya, dilihat dari daftar kegiatan pemanfaatan jasa lingkungan pada pasal 10 ayat 2 , maka "kompensasi" hanya dibebankan kepada kegiatan yang memanfaatkan jasa lingkungan sepanjang jasa lingkungannya masih ada. Mereka yang memperoleh keuntungan dengan jalan menghilangkan jasa lingkungan, justru tidak termasuk ke dalam mereka yang terkena kewajiban membayar "kompensasi".

2. Kerancuan antara konsep kompensasi dan pertanggungjawaban perdata

Kewajiban melakukan pembayaran terhadap pemanfaatan jasa lingkungan, oleh RUU disebut dengan istilah "kompensasi". Dari 
sisi istilah, hal ini akan menimbulkan kerancuan, mengingat istilah "kompensasi" biasanya merujuk kepada adanya kerugian. Dan kompensasi ini dibayarkan kepada mereka yang mengalami kerugian. Pertanyaannya, siapakah yang mengalami kerugian dari penggunaan jasa lingkungan ini?

RUU Jasling juga memiliki kerancuan dalam mengartikan kompensasi dengan pertanggungjawaban perdata. Di satu sisi, pasal 45 mengatakan bahwa mereka perbuatan melawan hukum hanya terkait dengan mereka yang tidak membayar kompensasi, padahal perbuatan melawan hukum bisa terkait dengan terciptanya kerugian pada diri seseorang yang diakibatkan penggunaan jasa lingkungan oleh orang lain. Di sisi lain, pasal 46 juga keliru dalam mengartikan tanggung jawab mutlak. Lagi, secara teoritis tanggung jawab mutlak hanya muncul dari adanya kerugian, dan bukan hanya karena seseorang menerima manfaat dari jasa lingkungan. Lebih dari itu, tanggung jawab mutlak (strict liability) biasanya hanya dibatasi oleh kerugian yang muncul karena bencana alam (act of god), keadaan terpaksa (force major), atau kesalahan pihak lain (termasuk kesalahan mereka yang mengalami kerugian) ${ }^{33}$ Anehnya, pasal 46 ayat 2 memberikan pengecualian atas tanggung jawab mutlak yang sama sekali berbeda dari teori yang ada. Menurut ayat ini, pengecualian terjadi jika pemanfaat jasa lingkungan "dapat membuktikan bahwa besarnya kompensasi sama dengan besarnya manfaat ekonomi yang diterimanya."

3. Polluter pays principle sudah tidak relevan?

Penjelasan umum RUU Jasling menyatakan bahwa salah satu alasan mengapa perlu dikembangkan instrumen ekonomi (dalam bentuk berbagai charges) adalah karena "pembiayaan melalui "polluters pay principle" sudah tidak memadai lagi bagi sumber pendanaan pemulihan kerusakan lingkungan hidup".

Penulis berpendapat bahwa pandangan ini sangat terburu-buru dan rancu. Berbeda dengan RUU Jasling, asas pencemar membayar (the polluter pays principle) bukannya tidak memadai dan harus diganti dengan pendekatan lain, tapi justru belum terlalu optimal dilaksanakan. Lagi pula, skema pembayaran kompensasi berdasarkan charges tidak lain merupakan salah satu bentuk

${ }^{33}$ Lihat misalnya pengecualian atas tanggung jawab mutlak menurut Pasal 35 UU 
instrumen untuk melaksanakan asas pencemar membayar (the polluter pays principle). ${ }^{34}$

4. Mitigasi Gas Rumah Kaca tidak diatur dengan jelas

Issue perubahan iklim disebutkan beberapa kali di dalam penjelasan umum, tapi sama sekali tidak ada pasal yang terkait dengan upaya mitigasi Gas Rumah Kaca. Dalam hal ini pun yang terkena kewajiban membayar kompensasi adalah para penghasil GRK, sepanjang mereka memanfaatkan rosot karbon dari vegetasi (pasal 10 ayat 2 huruf c). Apabila mereka tidak memanfaatkan sequestrasi karbon oleh vegetasi (hutan) maka mereka bebas dari kewajiban membayar kompensasi.

\section{Kesimpulan}

Secara teoritis, penggunaan instrumen ekonomi sebagai alat untuk melakukan internalisasi eksternalitas dapat diterapkan ke dalam berbagai bentuk kebijakan lingkungan, mulai dari penerapan pajak lingkungan, sistem dana talangan/jaminan, sampai pada jual-beli "izin/jatah pencemaran". Kemungkinan penerapan sistem ini telah disebutkan di dalam beberapa undang-undang di Indonesia, misalnya di dalam Undang-undang pengelolaan lingkungan hidup tahun 1997 dan UU Energi tahun 2007. Meskipun sepertinya sudah cukup dikenal di Indonesia, instrumen ekonomi sering kali disalahartikan bukan sebagai upaya untuk mendorong penaatan dan internalisasi biaya lingkungan, tetapi sebagai upaya untuk memperkecil atau bahkan menghilangkan peran Pemerintah di dalam pengelolaan lingkungan hidup.

Dari uraian di atas, terlihat bahwa instrumen ekonomi sama sekali tidak menghilangkan peran Pemerintah. Justru sebaliknya, dalam penerapan instrumen ekonomi, Pemerintah memiliki peran yang sentral dan sangat besar, mulai dari peran dalam bentuk kebijakan, izin, pengawasan, dan pemberian sanksi. Di samping itu, instrumen ekonomi pun bukanlah merupakan sebuah obat mujarab yang pasti bisa menyembuhkan lemahnya penaatan dan penegakan hukum di Indonesia. Tulisan ini justru memperlihatkan bahwa instrumen ekonomi pun memiliki kelemahankelemahan, sehingga meskipun tidak selamanya harus ditolak, instrumen

${ }^{34}$ Lihat misalnya: A.G. Wibisana, "Three Principles of Environmental Law: The Polluter-Pays Principle, the Principle of Prevention, and the Precautionary Principle", dalam: dalam M. Faure dan N. Niessen (eds.), "Environmental Law in Development: Lessons from the Indonesian Experience", (Cheltenham: Edward Elgar, 2006), hal. 25-37. 
ekonomi hanya dapat diterapkan dengan berbagai macam caveats. Dalam tulisan ini juga ditunjukkan bahwa instrumen ekonomi dapat berarti sangat luas, dan tidak hanya terbatas pada apa yang disebut sebagai "user charge".

Penulis memperlihatkan bahwa RUU Jasling berangkat dari pemahaman yang keliru dan sangat sempit mengenai instrumen ekonomi, sebab RUU ini menafsirkan instrumen ekonomi hanya sebatas pada user charge. Di samping itu, jika yang diinginkan adalah untuk penerapan instrumen ekonomi, maka yang dibuat bukanlah RUU, tetapi cukup dengan Peraturan Pemerintah, sebab kemungkinan penerapan instrumen ekonomi bagi pendanaan lingkungan telah diatur di dalam UU No. 23/1997 tentang Pengelolaan Lingkungan Hidup.

Penulis menyimpulkan bahwa dorongan utama yang menyebabkan lahirnya RUU Jasling bukanlah kebutuhan akan pendanaan lingkungan, tetapi pembentukan sebuah lembaga baru, Komisi Pengelolaan Jasa Lingkungan, yang sifatnya independen. Lebih jauh lagi, Penulis juga melihat bahwa semangat yang dibangun oleh RUU Jasling adalah semangat privatisasi jasa lingkungan. $\mathrm{Hal}$ ini dapat ditunjukkan dari diadopsinya oleh RUU Jasling pandangan yang menyatakan bahwa ditempatkannya sumber daya alam (SDA) sebagai public goods akan mengarah pada kehancuran SDA tersebut. Di samping itu, privatisasi juga terjadi pada diserahkannya tugas-tugas Komisi, termasuk tugas dalam hal perencanaan, pelaksanaan, dan pengawasan kepada pihak swasta.

Penulis berpendapat bahwa semangat yang diusung oleh RUU Jasling bertentangan dengan pasal 33 UUD 1945, dan karenanya harus ditolak. 
Lampiran 1. Instrumen Ekonomi yang Diterapkan di Negara Lain

\begin{tabular}{|c|c|c|c|c|c|c|c|c|c|c|c|c|}
\hline \multirow{2}{*}{ Country } & \multicolumn{4}{|c|}{ Effluent charge } & \multirow{2}{*}{$\begin{array}{l}\text { User } \\
\text { Charge }\end{array}$} & \multirow{2}{*}{$\begin{array}{l}\text { Product } \\
\text { Charge }\end{array}$} & \multirow{2}{*}{$\begin{array}{c}\text { Adminisrative } \\
\text { charge } \\
\text { (licensing ond } \\
\text { contrd) } \\
\checkmark\end{array}$} & \multirow{2}{*}{$\begin{array}{c}\text { Tox } \\
\text { differentiation }\end{array}$} & \multirow{2}{*}{$\begin{array}{c}\text { Subsidies } \\
\text { (grants, soft } \\
\text { laans, tox } \\
\text { allowances) }\end{array}$} & \multirow{2}{*}{$\begin{array}{l}\text { Depasit } \\
\text { Refund } \\
\text { System }\end{array}$} & \multicolumn{2}{|c|}{ Market Creation } \\
\hline & Air & $\begin{array}{c}\text { Water } \\
\checkmark\end{array}$ & $\begin{array}{c}\text { Woste } \\
\checkmark\end{array}$ & Noise & & & & & & & $\begin{array}{c}\text { Emission } \\
\text { trading }\end{array}$ & $\begin{array}{c}\text { Market } \\
\text { intervention }\end{array}$ \\
\hline Belgium & & & $\checkmark$ & & $\checkmark$ & & $\checkmark$ & & & & & \\
\hline Canada & & & & & $\checkmark$ & & & & $\checkmark$ & $\checkmark$ & & \\
\hline Denmark & & & & & $\checkmark$ & & $\checkmark$ & $\checkmark$ & $\checkmark$ & $\checkmark$ & & \\
\hline Finland & & & & & $\checkmark$ & $\checkmark$ & $\checkmark$ & & $\checkmark$ & $\checkmark$ & & $\checkmark$ \\
\hline France & $\checkmark$ & $\checkmark$ & & $\checkmark$ & $\checkmark$ & $\checkmark$ & $\checkmark$ & & $\checkmark$ & & & \\
\hline Germany & & $\checkmark$ & & $\checkmark$ & $\checkmark$ & $\checkmark$ & $\checkmark$ & $\checkmark$ & $\checkmark$ & & & \\
\hline Italy & & $\checkmark$ & & & $\checkmark$ & $\checkmark$ & $\checkmark$ & & & & & \\
\hline Japan & $\checkmark$ & & & $\checkmark$ & $\checkmark$ & & & & & & & \\
\hline Netherlands & & & $\checkmark$ & $\checkmark$ & $\checkmark$ & & $\checkmark$ & $\checkmark$ & $\checkmark$ & $\checkmark$ & & $\checkmark$ \\
\hline Norway & & & & & $\checkmark$ & $\checkmark$ & $\checkmark$ & & $\checkmark$ & $\checkmark$ & & \\
\hline Sweden & & & & & $\checkmark$ & $\checkmark$ & $\checkmark$ & $\checkmark$ & $\checkmark$ & $\checkmark$ & & \\
\hline Switzerland & & & & $\checkmark$ & $\checkmark$ & & & $\checkmark$ & & & & \\
\hline UK & & & & $\checkmark$ & $\checkmark$ & & $\checkmark$ & $\checkmark$ & & & & \\
\hline USA & & & $\checkmark$ & $\checkmark$ & $\checkmark$ & $\checkmark$ & & & $\checkmark$ & & $\checkmark$ & \\
\hline
\end{tabular}

Sumber: D.W. P earce dan R.K. Tumer, 1990, Economics of Natural Resources and the Enviroment, hai. $174^{35}$

${ }^{35}$ Tulis an Pearce den Turner ini didas arkan pada laporan Opschoor dan Vos tahun 1989. Tentu saja saat ini teiah terjadi banyak perubahan di dalam penerapan instrumen ekonomi di negara-negara tersebut. Misalnya saja, saat ini penggunaan tradeable permits telah banyak diadopsi dibeberapa negara selain dari pada AS. Mekanisme ini terutama berupa carbon trading. Sebagai perbandingan atas paparan Pearce dan Turner, lihat misalnya laporan OECD tahun 1999 seperti dikutip oleh Perman, et al., dalam: R. Perman, et al, 1999, Natural Resources and Environmental Economics, 2nd ed (Essex: Longman), hal. 221 
Lampiran 2. Instrumen Ekonomi di Inggris

\begin{tabular}{|c|c|}
\hline Type of Instruments & General description \\
\hline \multicolumn{2}{|l|}{ Charges } \\
\hline Effluent charges & $\begin{array}{l}\text { Paid on discharges into the } \\
\text { environment and are based on the } \\
\text { quantity and/or quality of the effluent }\end{array}$ \\
\hline Incentive effluent charges & $\begin{array}{l}\text { Revenue collected via the charge is not } \\
\text { returned to the polluter }\end{array}$ \\
\hline Distributive effluent charges & $\begin{array}{l}\text { Revenue collected via the charge is } \\
\text { returned to the polluter, in the form of } \\
\text { subsidies for new pollution control } \\
\text { equipment }\end{array}$ \\
\hline User charges & $\begin{array}{l}\text { Payments for the cost of collective or } \\
\text { public treatment of effluents }\end{array}$ \\
\hline Product charges/tax differentiation & $\begin{array}{l}\text { Additions to the price of products, whic } \\
\text { are polluting or are difficult to dispose } \\
\text { of, the former have a revenue-raising } \\
\text { feature }\end{array}$ \\
\hline Administrative charges & Control and authorisation fees \\
\hline \multicolumn{2}{|l|}{ Subsidies } \\
\hline Grants & $\begin{array}{l}\text { Non-repayable forms of financial } \\
\text { assistance, contingent on the adoption } \\
\text { of pollution abatement measures }\end{array}$ \\
\hline Soft loans & $\begin{array}{l}\text { Loans linked to abatement measures } \\
\text { and carrying below-market rates of } \\
\text { interest }\end{array}$ \\
\hline Tax allowances & $\begin{array}{l}\text { Allows accelared depreciations, tax or } \\
\text { charge exemptions or rebates if certain } \\
\text { pollution abatement measures are } \\
\text { adopted }\end{array}$ \\
\hline Deposit refund-system & $\begin{array}{l}\text { Systems in which surcharges are laid on } \\
\text { the price of potenntally polluting, a } \\
\text { refund of the surcharge is given on the } \\
\text { return of the product or its residuals }\end{array}$ \\
\hline Market creation & $\begin{array}{l}\text { Artificial markets in which actors can } \\
\text { buy and sell "rights" for actual or }\end{array}$ \\
\hline
\end{tabular}




\begin{tabular}{|l|l|}
\hline $\begin{array}{l}\text { Emissions trading (bubles, offsets, } \\
\text { netting and banking) }\end{array}$ & $\begin{array}{l}\text { potential pollution } \\
\text { Wthin a plant, within a firm, or among } \\
\text { different firms }\end{array}$ \\
\hline Market intervention & $\begin{array}{l}\text { Price intervention to stabilise markets, } \\
\text { typically secondary materials (recycled } \\
\text { markets) }\end{array}$ \\
\hline Liability insurance & $\begin{array}{l}\text { Polluter liability leading to insurance } \\
\text { market }\end{array}$ \\
\hline
\end{tabular}

Sumber: D.W. Pearce dan R.K. Turner, 1990, Economics of Natural Resources and the Environment, hal. 172. 


\section{Daftar Pustaka}

Barde, J.P. "Environmental Policy and Policy Instruments". Dalam: H. Folmer, H.L. Gabel, dan H. Opschoor (eds.). Principles of Environmental and Resource Economics: A Guide for Students and Decision-Makers. Aldershot: Edward Elgar, 1995.

Bell, S. dan D. McGillivray. Environmental Law. 5th edition. London: Blackstone Press, 2000.

Common, M. dan S. Stagl. Ecological Economics: an Introduction. Cambridge: Cambridge University Press, 2005.

Costanza, R. dan L. Cornwell."The 4P Approach to Dealing with Scientific Uncertainty". Environment, Vol. 34, No. 9, 1992.

Costanza, R. dan C. Perrings."A Flexible Assurance Bonding System for Improved Environmental Management". Dalam: Ecological Economics, Vol. 2, 1990.

De Kock, S."Government Financial Incentive for the Protection of the Environment". Dalam: M. Bothe (ed.). Trends in Environmental Policy and Law. Gland: IUCN, 1980.

Dudek, D.J.; R.B. Stewart, dan J.B. Wiener. "Technology-Based Approaches versus Market-Based Approaches". Dalam P. Sands (ed.). Greening International Law. London: Earthscan Publications, 1993.

Estrin, S. dan D. Laidler. Introduction to Microeconomics, $4^{\text {th }}$ Edition. New York: Harvester Wheatsheaf, 1995.

Faure, M. "Environmental Law and Economics". Maastricht: METRO, 2001.

Faure, M.; M. Peeters, dan A.G. Wibisana. "Economic Instruments: Suited to Developing Countries?". Dalam: M. Faure dan N. Niessen (eds.). Environmental Law in Development: Lessons from the Indonesian Experience. Cheltenham: Edward Elgar, 2006..

Ferge, Z. "What are the State Functions that Neoliberalism Wants to Eliminate?". Dalam: A. Anton, et al. (ed.). Not for Sale: In Defense of Public Goods. Oxford: Westview Press, 2000.

Fisk, M. "Surviving with Dignity in a Global Economy: The Battle for Public Goods". Dalam: A. Anton, et al. (ed.). Not for Sale: In Defense of Public Goods. Oxford: Westview Press, 2000. 
Greenwood, B. "Looking Ahead: Environmental Regulation: A Future". Dalam: A.E. Boyle (ed.). Environmental Regulation and Economic Growth. Oxford: Oxford University Press, 1994.

Groosman, B. "Pollution Tax". Dalam: B. Bouckaert and G. de Geest (eds.). Encyclopedia of Law and Economics Volume II: Civil Law and Economics. Cheltenham: Edward Elgar, 2000.

Hardin, G. "The Tragedy of the Commons". Dalam: Science, Vol. 162, 1968.

Holmstrom, N. "Rationality, Solidarity, and Public Goods". Dalam: A. Anton, et al. (ed.). Not for Sale: In Defense of Public Goods. Oxford: Westview Press, 2000.

Kolstad, C.D. Environmental Economics. Oxford: Oxford University Press, 2000.

Light, A. "Public Goods, Future Generations, and Environmental Quality". Dalam: A. Anton, et al. (ed.). Not for Sale: In Defense of Public Goods. Oxford: Westview Press, 2000.

Löfgren, K.G. "Market and Externalities". Dalam: H. Folmer, H.L. Gabel and H. Opschoor (eds.). Principles of Environmental and Resource Economics: A Guide for Students and Decision-Makers. Aldershot: Edward Elgar, 1995.

Mansfield, E. Principles of Microeconomics. New York: W.W. Norton \& Company, 1983.

Oates, W. dan W. Baumol. "Instrument for Environmental Policy". Dalam: W.E. Oates (ed.). The Economics of Environmental Regulation. Cheltenham: Edward Elgar, 1996.

Ogus, A. "Nudging and Rectifying: the Use of Fiscal Instruments for Regulatory Purposes". Dalam: Legal Studies, Vol. 19, 1999.

Pearce, D.W. dan R.K. Turner. Economics of Natural Resources and the Environment. Baltimore: the Johns Hopkins University Press, 1990.

Perman, R., et al. Natural Resources and Environmental Economics, 2nd ed. Essex: Longman, 1999.

Sagoff, M. The Economi of the Earth: Philosophy, Law, and the Environment. Cambridge: Cambridge University Press, 1996.

Shiva, V. Earth Democracy: Justice, Sustainability, and Peace. Cambridge, MA: South End Press, 2005. 
Solberg, E.E.J. Intermediate Microeconomics. Texas: Business Publication, 1982.

Stavins, R.N."Experience with Market-based Environmental Policy Instruments". Dalam: K.G. Mäler dan J.R. Vincent (eds.). Handbook of Environmental Econmics Volume I: Environmental Degradation and Institutional Responses. Amsterdam: Elsevier, 2003.

Turner, R.K.; D. Pearce, and I. Bateman. Environmental Economics: an Elementary Introduction. New York: Harvester Wheatsheaf, 1994.

Wibisana, A.G. "Three Principles of Environmental Law: The Polluter-Pays Principle, the Principle of Prevention, and the Precautionary Principle". Dalam: M. Faure dan N. Niessen (eds.). Environmental Law in Development: Lessons from the Indonesian Experience. Cheltenham: Edward Elgar, 2006. 